\title{
1. SEISMIC STRUCTURE OF MIDDLE VALLEY NEAR SITES 855-858, LEG 139, JUAN DE FUCA RIDGE ${ }^{1}$
}

\author{
K.M.M. Rohr ${ }^{2}$ and U. Schmidt ${ }^{2}$
}

\begin{abstract}
Geologic structure around holes drilled during Ocean Drilling Program Leg 139 is interpreted from single- and multichannel seismic reflection data. The holes are in a fault block of a sedimented rift valley (Middle Valley) of the Juan de Fuca ridge. This block is bound by two west-facing normal faults that separate crustal blocks with significantly different sedimentary sequences. Sediments in the drilled block are 200 to $500 \mathrm{~ms}$ thick and are underlain by nearly flat, high-amplitude reflectors. These events are $500-1000 \mathrm{~m}$ in width and appear to step down to the west towards younger crust. The events are interpreted to be the top of a sediment-sill complex that formed during simultaneous volcanism, extension, and sedimentation. Four groups of these bright reflectors can be correlated along strike in the fault block. Because they are elongated along strike, we infer that they are sills that were intruded as magma welled up along extensional faults. Several previously unmapped west-facing normal faults have been interpreted on the west side of the fault block; their offsets increase with depth and range from 10 to $100 \mathrm{~ms}$. Contrary to a previous interpretation, we show that the character of sediments and basement across the eastern block-bounding fault near Site 855 is different and that this fault has been active for some time. Site 856 and another hydrothermal mound to the north are associated with shallow basalt reflectors significantly smaller in their lateral extent than the elongated sills within the fault block. Sites 857 and 858 are near the western block-bounding fault; Holes $857 \mathrm{~A}$ and $857 \mathrm{C}$ are separated by a small offset fault. A region no more than $2 \mathrm{~km}$ along strike around Site 858 appears to have been uplifted by tens of meters. This uplift is presumably related to late-stage igneous activity documented by drilling.
\end{abstract}

\section{INTRODUCTION}

Middle Valley is a sedimented rift valley on the Juan de Fuca ridge formed by simultaneous volcanism, extensional faulting, and sedimentation (Fig. 1). It was initially formed by intermediate-rate spreading, but the present rate of extension in Middle Valley is unknown, because recent extension is occurring $15 \mathrm{~km}$ to the west. Davis and Villinger (1992) have described the major structural features of the valley; we examine seismic reflection data to delineate the structural style of the upper crust in this region. After describing the general structural style of the drilled fault block, we discuss each site individually.

\section{METHODS}

To investigate seismic structure around the Leg 139 sites we used single-channel seismic reflection data collected in 1988 and 1989 and multichannel data collected in 1989 (Davis and Villinger, 1992; Rohr et al., 1992) (Fig. 2). These surveys form a closely spaced suite of subparallel lines over a 7-km swath of the valley concentrated near active hydrothermal vents. The single-channel data were collected using a $0.655 \mathrm{~L}\left(40 \mathrm{in}^{3}\right)$ airgun and recorded digitally at a 4-ms sample rate. The dominant frequency differs between the two single-channel surveys by tens of hertz, but generally is about $100 \mathrm{~Hz}$. Both surveys started recording $2500 \mathrm{~ms}$ after the source fired. Every 9 th trace of the 1988 survey required a $15-\mathrm{ms}$ static correction because of a problem in the recording system. The 1989 survey is severely contaminated by $60 \mathrm{~Hz}$ noise because of hardware problems undetected during recording. The multichannel data were collected with a $134 \mathrm{~L}\left(8200 \mathrm{in}^{3}\right)$ airgun array and the dominant frequency is $30 \mathrm{~Hz}$. The streamer was $3600 \mathrm{~m}$ long, consisting of 144 groups; data were recorded at a 4-ms sampling rate. Shotpoints with 50-m spacing resulted in 36-fold common-depth point (cdp) gathers. Processing consisted of an f-k filter to

\footnotetext{
${ }^{1}$ Mottl, M.J., Davis, E.E., Fisher, A.T., and Slack, J.F. (Eds.), 1994. Proc. ODP, Sci. Results, 139: College Station, TX (Ocean Drilling Program).

${ }^{2}$ P.O. Box 6000, Pacific Geoscience Centre, Geological Survey of Canada. Sidney, B.C. V8L 4R9, Canada.
}

shotpoints, gather to cdp mode, velocity analysis, normal move-out, stack and migration. Acquisition and processing are further described in Rohr et al. (1992).

All surveys were navigated by Global Positioning System (GPS) and Loran C. Processing corrects Loran $\mathrm{C}$ data to be consistent with GPS data. The airgun array was fired every $50 \mathrm{~m}$, as determined by real time navigation, whereas the single $0.65 \mathrm{~L}$ airgun was fired every $8 \mathrm{~s}$ during the single-channel survey. Tying interpretations between the surveys poses problems in some locations. The biggest assumption with the single-channel data is that the ship maintained a constant speed.

When comparing the single- and multichannel data sets, the differences in resolution are worth remembering. After gathering into cdp's, the trace-spacing of the multichannel data is $12.5 \mathrm{~m}$ and the trace spacing for the single-channel data is $50-60 \mathrm{~m}$. The wavelength of the multichannel data in water is $50 \mathrm{~m}$ and the first Fresnel zone is $500 \mathrm{~m}$ in diameter; the wavelength of the single-channel data is $15 \mathrm{~m}$ and the Fresnel zone is $300 \mathrm{~m}$ in diameter. The single-channel data are more sensitive to scattering and do not always have sufficient penetration to reach basement. On the 1989 single-channel survey the $0.655 \mathrm{~L}$ airgun produced a ghost $60 \mathrm{~ms}$ after the primary pulse (see Fig. 3) that interferes with subsurface events and limits interpretations. The multichannel data are at such low frequencies that they provide little detail of the sediments, but better basement definition.

\section{SEISMIC STRUCTURE \\ Drilled Fault Block}

During Leg 139, four sites were drilled between two west-facing normal faults along the eastern side of Middle Valley (Fig. 1). The westernmost of these two faults bounds the currently active central graben thought to contain the most recently formed crust; slightly older crust (200-400 kyr) lies between the two faults (Davis and Villinger, 1992). For simplicity in the following discussion we will refer to the graben-bounding fault zone as "the 858 fault zone" and the easternmost fault as "the 855 fault" because of their proximity to these sites. Bathymetry of the drilled fault block is quite uniform along strike. From south to north over the $7 \mathrm{~km}$ surveyed swath, the 


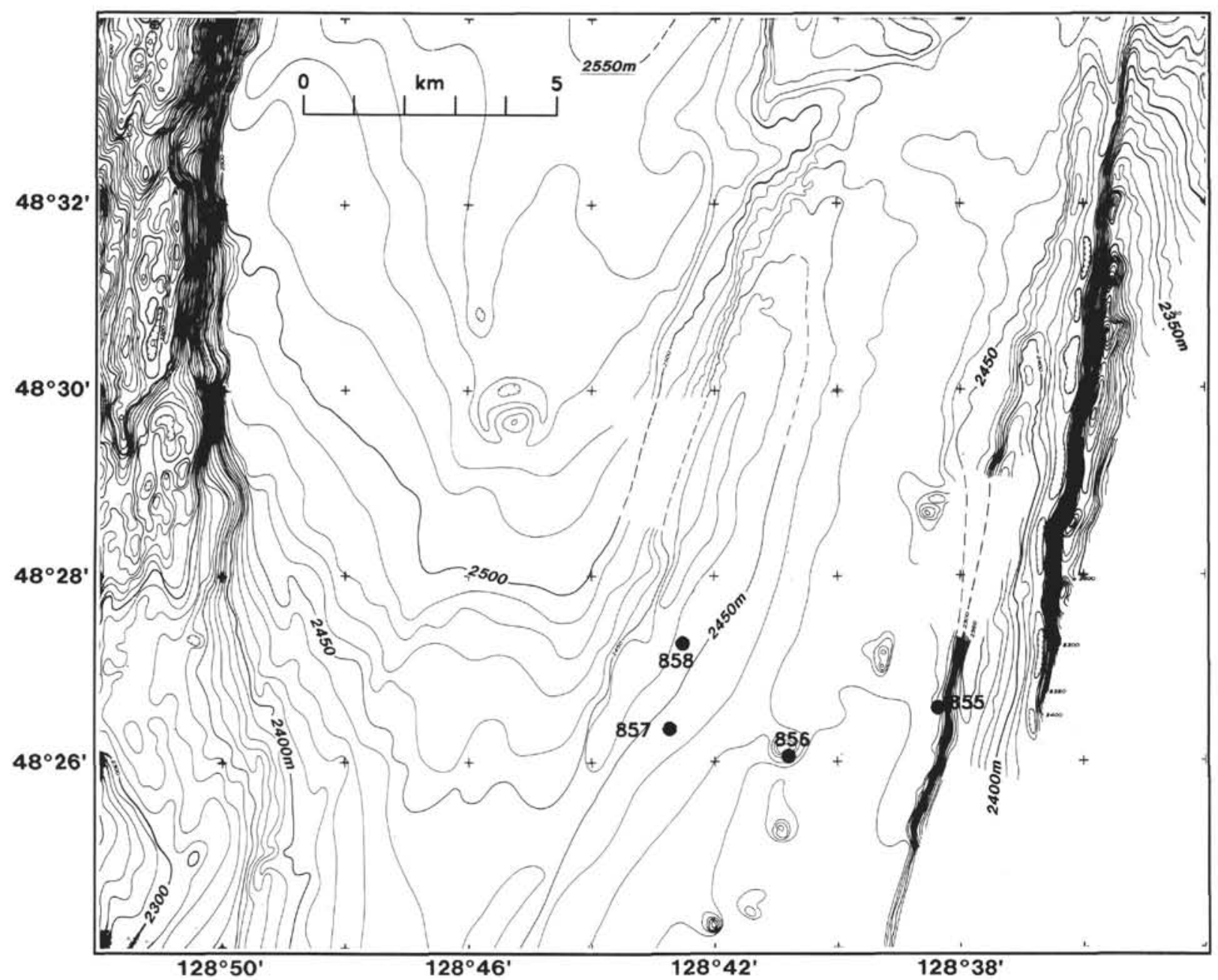

Figure 1. Sea Beam bathymetry of Middle Valley; contours are $10 \mathrm{~m}$ (after Davis and Villinger, 1992). Fault block drilled during Leg 139 lies between the 858 and 855 faults.

858 fault zone changes from a simple offset to a $1.5-\mathrm{km}$-wide fault zone and increases in offset from 30 to $70 \mathrm{~m}$ on the seafloor to the north (Fig. 1). This increase in offset is accomplished by relative subsidence of the central graben because the crest of the footwall varies by only $10 \mathrm{~m}$ in depth within the surveyed area; the graben deepens by $60 \mathrm{~m}$.

As the 858 fault zone widens northward, the crest of the footwall moves closer to the 855 fault by about $1 \mathrm{~km}$. Reflectors can be traced up to the 858 fault zone on line 88-14 (Fig. 4D) whereas structure within the crest is more disrupted from line 89-20 (Fig. 3) north.

Between the 858 fault zone and the 855 fault the seafloor drops 50 $m$ towards the 855 fault. A sequence of reflections immediately below the seafloor thickens from 60 to $90 \mathrm{~ms}$ towards the 855 fault in all datasets (e.g., Fig. 3, 4, and 5). The time interval between individual reflectors within the wedge increases towards the 855 fault and some events onlap the 858 fault zone footwall, a classic sequence indicating tilting during deposition. This sequence would usually be interpreted to indicate movement on the 855 fault, but uplift on the 858 footwall could also produce onlap and fanning reflectors. Assuming an interval velocity of $1600 \mathrm{~m} / \mathrm{s}$ (see Rohr and Gröschel-Becker, this volume), either $48 \mathrm{~m}$ of offset on the 855 fault, or $61 \mathrm{~m}$ of uplift on the 858 fault zone, or some combination of these offsets could have occurred.

Bright reflectors within and below sediments are hundreds of meters to a kilometer wide and are common west of the 855 fault. Their amplitudes are two to three times that of the seafloor (Fig. 6) as can be produced by hard rock within soft sediments. The hard rock is probably basalt or diabase; these reflections have been interpreted as sills (Davis and Villinger, 1992). We define bright events underlain by high frequency reflectors on the multichannel data to be isolated sills within sediments and bright events underlain by a low frequency train of events to be the top of basement. Basement at Site 857 consists of interlayered sills and sediments (Shipboard Scientific Party, 1992c); synthetic seismograms based on this sequence result in a low frequency interference train of events (Rohr and Gröschel-Becker, this volume). For example, the event $150 \mathrm{~ms}$ below seafloor (bsf) at Site 856 (Fig. 7) is a sill and not basement, whereas the event $480 \mathrm{~ms}$ under Site 857 (Fig. 8) is the top of basement.

Four groups of sills have been correlated from line to line (Figs. 3 and 4). The sills are up to $7 \mathrm{~km}$ long, approximately $1 \mathrm{~km}$ wide on unmigrated sections, and parallel to the primary extensional faults (Fig. 9). Group W occurs either on or immediately adjacent to the 858 fault zone (Figs. 3, 4, and 5) and group X occurs beneath a smaller offset fault discussed below (Figs. 3 and 4).

Several small offset normal faults, A, B, and C, occur within sediments just east of the 858 fault zone (Figs. 4 and 9); they have no major topographic expression. Both appear to step east north of Site 858. They offset a distinctive set of parallel events, which consists of a bright reflector (horizon $\mathrm{S}_{\mathrm{b}}$ ) that is equal in amplitude to the seafloor (Fig. 6a), and a set of high frequency events above it. Its amplitude suggests that horizon $\mathrm{S}_{\mathrm{b}}$ is a semiconsolidated or altered sediment as 


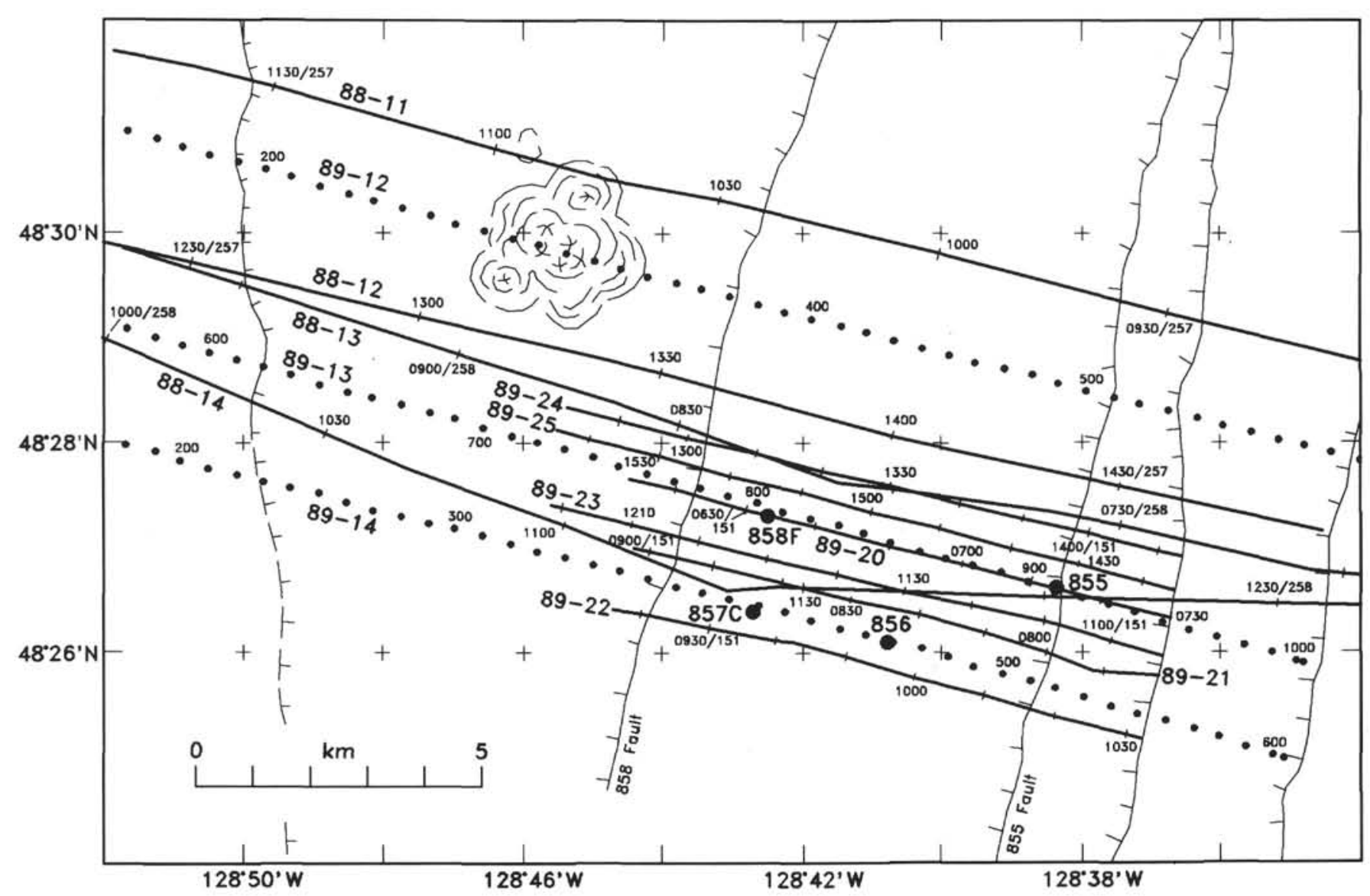

Figure 2. Location of single- and multichannel seismic reflection data discussed in this chapter (after Davis and Villinger, 1992). Lines 89-12, 13, 14 (dotted lines) are multichannel; numbers along the lines are shotpoint locations. Dots are spaced every 10 shotpoints. The single-channel data (solid lines) have shot times annotated on the lines.

opposed to hard rock, which would result in amplitudes two to three times larger. Fault A clearly offsets these reflectors by $100 \mathrm{~ms}(85 \mathrm{~m}$ at $1700 \mathrm{~m} / \mathrm{s}$ ) on line $88-13$ (Figs. $4 \mathrm{C}$ and 10 ) and is defined on $88-12$ (Fig. 4B) and 88-11 (Fig. 4A) as the western limit of these reflectors. Fault B can be traced $4 \mathrm{~km}$ from line $88-12$ (Fig. 4B) to $89-22$ but does not occur on line $89-12$ or $88-11$ (Fig. 4A). It offsets the interpreted reflectors by 45 to $60 \mathrm{~ms}$ (38-51 m using an interval velocity of 1700 $\mathrm{m} / \mathrm{s}$ ) and occurs $1 \mathrm{~km}$ east of Site 857 (Fig. 9). Fault $\mathrm{C}$ is observed between Holes $857 \mathrm{~A}$ and $857 \mathrm{C}$ and is discussed in the section on Site 857. Given minor problems in navigation, the exact location of the faults could be in error by hundreds of meters. Alternatively, they could occur as short en-echelon segments as opposed to the more continuous traces we have drawn (Fig. 9).

Horizon $\left(\mathrm{S}_{\mathrm{b}}\right)$ is approximately $180 \mathrm{~ms}$ bsf on lines $88-11$ (Fig. 4A) to $88-13$ (Fig. 4C), indicating little along-axis dip. Fault $B$ is the western limit of the associated sediment wedge from line 88-14 (Fig. 4D) to $88-12$ (Fig. 4B); fault $\mathrm{A}$ is its western limit (by definition) in the northern end of the survey area (Fig. 9). West of fault B the interpreted sedimentary section consists of a different set of reflectors, implying that sedimentation occurred after or during movement on those faults.

A shallow reflector has been interpreted on the 1988 single-channel data to highlight these structural relationships. While sections of $88-11,-12$, and -13 cannot be tied to $88-14$ (Fig. 4) in the crest of the 858 fault zone's footwall, they can be tied in the wedge. Differences in the frequency content between these lines result in errors of tens of $\mathrm{ms}$ on this tie. Within the survey area this reflector is shallowest immediately east of fault B and deepens to the east in the wedge and to the west with movement on the small normal faults A, B, and C within the 858 footwall.

\section{Site 855}

Site 855 holes were drilled in the hanging wall of the eastern basin-bounding fault (Fig. 1), referred to as the 855 fault. The migrated depth section (Fig. 11) shows the location and depths of Holes $855 \mathrm{~A}, 855 \mathrm{~B}$, and $855 \mathrm{C}$. Hole $855 \mathrm{D}$ is offset from the fault the same distance as Hole $855 \mathrm{C}$ but south of Holes $855 \mathrm{~A}, 855 \mathrm{~B}$, and $855 \mathrm{C}$ so was not drawn on Figure 11. An exact location of the surface break of the fault on this section is difficult to pinpoint, but the holes are positioned correctly relative to each other. A low-frequency shallow dipping event could be a contact between sediment and basalt. Whether this is a single fault or a combination of several steeply dipping faults is beyond the resolution of these data.

The Shipboard Scientific Party (1992a) believed that sediments correlate across the 855 fault from the rift valley to the footwall and therefore inferred that the fault formed recently. Our reexamination of the data (Figs. 12 and 13) shows that significant differences exist in the character of the basement and the sediments on either side of the fault, suggesting that the fault has been active for some time.

A comparison of single- and multichannel reflection data across the fault (Fig. 12) shows that the single-channel data do not penetrate past the sills occurring between 3.4 and $3.5 \mathrm{~s}$. Sediment thickness above these sills is similar to sediment thickness along the footwall, resulting in an apparent correlation. On profiles north and south (e.g., Figs. 4A and $4 \mathrm{~B}$ ), however, the depth to this sill increases by $50-100 \mathrm{~ms}$, while 


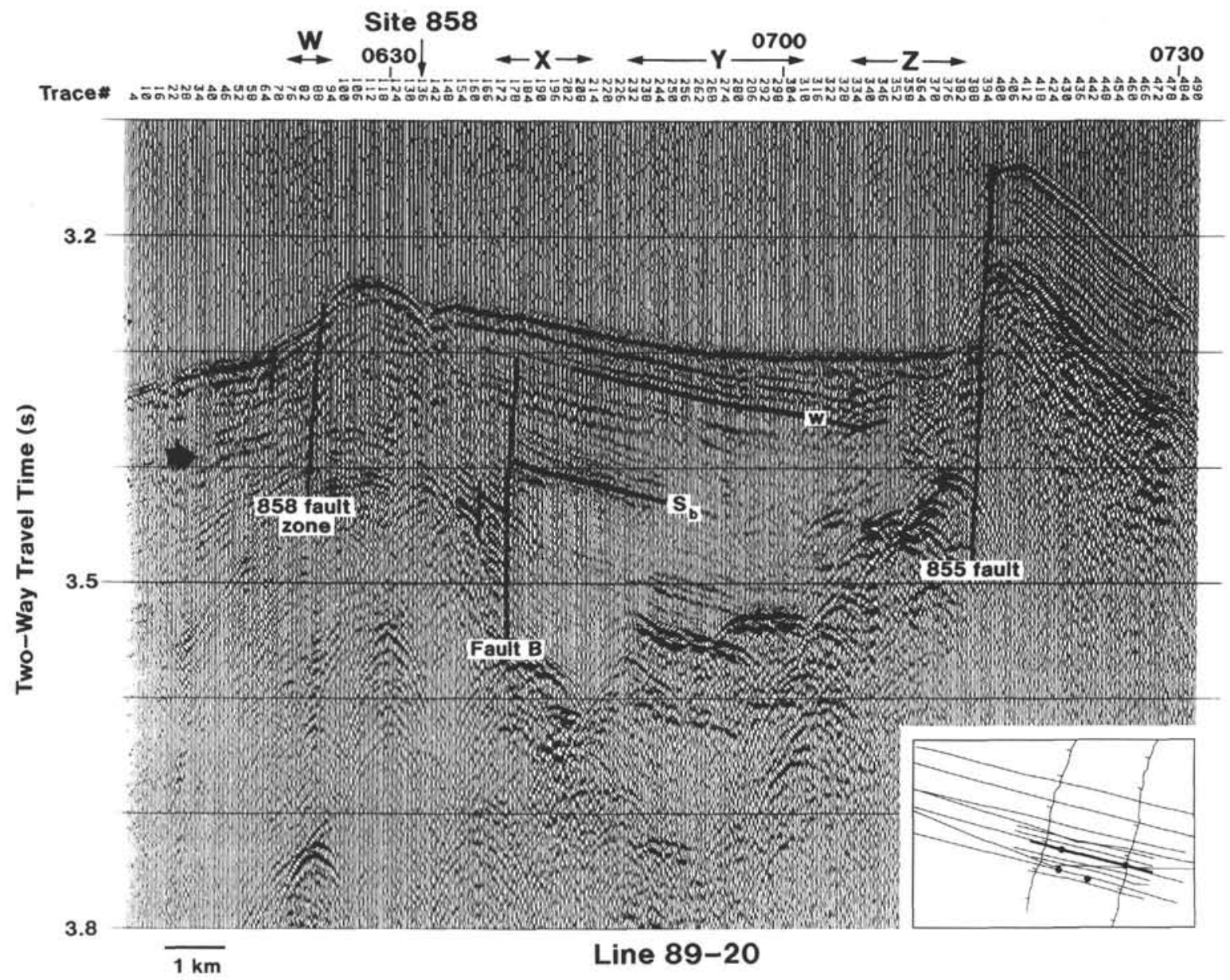

Figure 3. Single-channel profile across the eastern side of Middle Valley. Eastern basin bounding fault, the 855 fault, is at trace 390 ; the 858 fault zone is at trace 70. The lateral extent of sill groups W, X, Y, and Z are indicated. Arrow at left marks ghost of airgun source. Inset shows cartoon of Fig. 2; bold line indicates profile location.

sediment thickness on the footwall remains constant. The multichannel data have better penetration and have imaged another group of sills 200-300 ms below the first set. There must be sediments between the two sets of sills to allow such a clear image of the second set of sills at $3.6 \mathrm{~s}$ (see Rohr and Gröschel-Becker [this volume] for the seismic signature of closely spaced sills). The deeper set of sills may be the top of the sill-sediment complex making up basement within Middle Valley. East of the 855 fault a single bright event underlies sediments; it looks similar to sediment-basement contacts of oceanic crust formed in unsedimented rift valleys as observed around the world.

Aligning or flattening seafloor reflections heightens the differences between the sections on either side of the 855 fault (Fig. 13). Traces immediately west of the fault (see also Fig. 3) are disrupted and sedimentary sequences on either side of the fault are significantly different in character as well as thickness. The disturbed character of the sediments adjacent to the fault could be caused either by faulting itself, hydrothermal alteration, or debris flows from the fault face.

\section{Site 856}

Site 856 was drilled into a hill just north of massive sulfide mounds (Figs. 1 and 7). Since the wavelength of the multichannel data is on the order of the width of the hill, we have primarily recorded diffractions from it. The bright negative event underlying the hill (Fig. 7) is not observed on single-channel lines 89-21 (Fig. 3) or 89-22, which lie $500 \mathrm{~km}$ north and south of the hill, respectively. Reflectors are flat on either side of the hill (Fig. 7); three-dimensional effects of lateral velocity changes as well as slightly overmigrated diffractions affect reflections underneath the hill. The event 220 to $270 \mathrm{~ms}$ below the seafloor is seen on other reflection profiles and is probably a sill.

A plot of data recorded by the group of hydrophones closest to the airgun array shows that the hill is acoustically transparent (Fig. 14). Energy within the hill that shows up on the migrated section (Fig. 7) is difficult to interpret because of the three-dimensionality of the structure. Reflections from the adjacent flat seafloor can be traced under the hill (Fig. 14) because the Fresnel zone is $500 \mathrm{~m}$ in diameter. A bright event $180 \mathrm{~ms}$ under the hill has a simple waveform on the west side but becomes more complex to the east. A graph of the near trace of cdp 1750 shows that this bright event has the opposite polarity of the seafloor (Fig. 15), indicating that the seismic energy travelled into a material with lower acoustic impedance. Drilling encountered basalt at 112 and 120 mbsf in Holes 856A and 856B, respectively (Shipboard Scientific Party, 1992b); seismic energy travelling in basalt and reflecting off underlying sediments would have a negative polarity. Reflections from within a sill-sediment complex can cancel each other out, yet still produce a good reflection from the base. Unfortunately, no seismic lines passed directly over the sulfide mounds south of the hill sampled by Holes $856 \mathrm{G}$ and $856 \mathrm{H}$, so we have no record of their seismic signature.

Interval velocities were interpreted from cdp $1710500 \mathrm{~m}$ east of the hill using the Dix approximation on stacking velocities measured from semblance analysis. The top $225 \mathrm{~m}$ have a velocity of $1730 \mathrm{~m} / \mathrm{s}$.

Another hill was imaged by line $89-12$; it is also underlain by a bright reflector. This presumed sill is observed on $88-12$ (Fig. 4B, 
trace 360-380) but not on other lines. It measures 1.5 to $4 \mathrm{~km}$ alongstrike and is $2 \mathrm{~km}$ wide on $89-12$. On the single-channel line, reflections above the sill do not look disturbed or uplifted.

\section{Site 857}

Site 857 was drilled near the crest of the 858 fault zone footwall. Hole $857 \mathrm{C}$ lies between faults $\mathrm{C}$ and $\mathrm{B}$; Hole $857 \mathrm{~A}$ is separated from $857 \mathrm{C}$ by fault $\mathrm{C}$ (Fig. 8). Reflectors are offset on fault $\mathrm{C}$ by $10 \mathrm{~ms}$ near the seafloor but a group of reflectors at $3.5 \mathrm{~s}$ is offset $75 \mathrm{~ms}$ (Fig. 16). This fault shows up well on line $89-22500 \mathrm{~m}$ south of Site 857 and on line 88-14 (Fig. 4D). Our interpretation of this fault at the location of Hole 857A places it 150-200 ms bsf, but it does not appear to have been intersected by the hole. Using a velocity-depth function for $857 \mathrm{C}$ from Rohr and Gröschel-Becker (this volume), the base of Hole $857 \mathrm{~A}$ was at approximately $160 \mathrm{~ms}$ bsf and showed no evidence of faulting.

Lithologic boundaries were defined from cores by the degree of alteration (Shipboard Scientific Party, 1992c), but the gradual changes in alteration described result in small-amplitude seismic events (Rohr and Gröschel-Becker, this volume). An important question in trying to correlate lithologic units across faults is whether alteration occurred before or after faulting. If the fault moved after alteration, a corresponding event might be found on either side, but if alteration occurred after fault movement, no disruption would occur.

The Unit I/II lithologic boundary is in upper Pleistocene sediments (Shipboard Scientific Party, 1992c); it was defined at $25.2 \mathrm{mbsf}$ at Hole $857 \mathrm{~A}$ ( $33 \mathrm{~ms}$ bsf assuming a velocity of $1500 \mathrm{~m} / \mathrm{s}$ ). The small seismic event at this time appears to become shallower across fault $\mathrm{C}$ and then merges with the seafloor reflection (Fig. 8). There was no core recovery between 3 and 56 mbsf at Hole $857 \mathrm{C}$ to test this interpretation.

The subunit IIA to IIB lithologic boundary is defined by an increase in alteration and was correlated to the seismic section (Rohr and Gröschel-Becker, this volume). There is no obvious match to it across fault C or B on line 89-14 (Fig. 8). The stratigraphic sections on either side of these faults differ significantly because of simultaneous offset and deposition. The increase in alteration may have a different seismic signature depending on the sedimentary sequence in which it occurs, as well as the exact nature of the increasing grade of metamorphism.

Highly permeable zones were detected at 610 and $680 \mathrm{mbsf}$ in Hole $857 \mathrm{C}$ during packer/flowmeter tests. These results have been interpreted to indicate faulted zones, but there are no obvious offsets in the seismic reflection data at this level. If the fault were less than one-quarter wavelength in offset $(35 \mathrm{~m}$, assuming a $20 \mathrm{~Hz}$ signal in $2700 \mathrm{~m} / \mathrm{s}$ material) or occurred in only a fraction of the seismic data's Fresnel zone, it would not be clearly imaged.

\section{Site 858}

Hole $858 \mathrm{~F}$ was drilled into an active hydrothermal vent $1.6 \mathrm{~km}$ north of Site 857 (Fig. 1). The vent site is a $300-\mathrm{m}$ depression underlain by a bright reflector that is not seen elsewhere in the surveys studied (Fig. 17). Large seafloor reflection coefficients, as well as this bright event, have been interpreted to be the result of alteration of the upper sedimentary column (Rohr et al., 1993; Rohr and GröschelBecker, this volume). This site is $600 \mathrm{~m}$ from the crest of the 858 footwall and $1 \mathrm{~km}$ from fault B (Fig. 9). A bright reflector $500 \mathrm{~m}$ wide lies $300 \mathrm{~ms}$ bsf under the vent field. It was not imaged by the singlechannel data nor on any other multichannel data. Modelling well-log sonic data correlated this event to extrusive basalt flows (Rohr and Gröschel-Becker, this volume) with a chemical signature indicative of an off-axis origin (Shipboard Scientific Party, 1992d).

Within $500 \mathrm{~m}$ of the vent, shallow reflectors are uplifted (Figs. 17 and 18). While correlation of stratigraphy within the crest is difficult, horizon $\mathrm{S}_{\mathrm{b}}$ dips steeply and is approximately $40 \mathrm{~ms}$ shallower on lines 89-20 and 89-25 (Fig. 18) than on line 88-14 (Fig. 4D). On lines 88-13 (Fig. 4C) and 89-24 (Fig. 18) about $1 \mathrm{~km}$ north of the vent field horizon $\mathrm{S}_{\mathrm{b}}$ has not been uplifted.

Resistivity logs were correlated between Holes $857 \mathrm{C}$ and $858 \mathrm{~F}$ showing that an interpreted set of turbidite flows is $60 \mathrm{~m}$ shallower in $858 \mathrm{~F}$ relative to $857 \mathrm{C}$ (Shipboard Scientific Party, 1992c). One of the correlated units ( $110 \mathrm{mbsf}$ in Hole $858 \mathrm{~F}$ ) occurs at $130 \mathrm{~ms}$ bsf at Hole $858 \mathrm{~F}$ and $190 \mathrm{~ms}$ bsf at Hole $857 \mathrm{C}$ (Rohr and Gröschel-Becker, this volume). Comparing reflection sections across each hole (Fig. 19) shows the uplift between the two lines, as well as additional uplift immediately below the vent. The latter could be caused by higher velocities under the vent; well logs showed that seismic velocities were on average $200 \mathrm{~m} / \mathrm{s}$ higher under Site 858 than under Site 857 (Shipboard Scientific Party, 1992c and 1992d).

\section{CONCLUSIONS AND DISCUSSION}

During Leg 139, holes were drilled at four sites in the eastern section of Middle Valley, which is bound by two west-facing normal faults, the 855 fault and the 858 fault. Reflection character changes significantly across these faults. Both faults may have been active in the late Pleistocene and Holocene, resulting in formation of a wedge of sediments between them, which is $5 \mathrm{~km}$ wide and thickens to the east. Knowledge of the sedimentation rates is too poor (Shipboard Scientific Party, 1992c) to allow estimation of the length of time the 855 fault has been active. Upper crust of its footwall must have formed before massive amounts of sediment began pouring into Middle Valley, creating the distinctive sediment/sill-layered upper crust penetrated at Hole 857D.

Several small offset normal faults occur on the western edge of the faulted block; shallow sedimentary sequences change at each fault, implying that they were active during sedimentary deposition in the late Pleistocene and Holocene. Although tying seismic profiles from three different surveys can be difficult, these faults show up consistently on all three datasets. Their exact locations may be questioned, but their existence cannot. One or more of these small faults lies between Holes $857 \mathrm{C}$ and $858 \mathrm{~F}$. Uplift of sediments around Site 858 is restricted to an area 1-2 km long; additional uplift occurs immediately under the vent site at Hole $858 \mathrm{~F}$. The uplift is probably related to intrusions at depth associated with extrusive volcanic rocks drilled at the base of the hole.

Four groups of sills can be correlated on the reflection profiles; they are elongated parallel to the strike of the extensional faults. From the map view of the sills, we infer that magma welled up on extensional cracks to form the sills similar to fissure flows on the flanks of volcanos. A second possible interpretation is that a single large sill has been faulted and extended. Since the sills were picked from unmigrated sections, their mapped extent is wider than their real extent. The amount of extension to create the gaps between the reflectors would have to be nonuniform along strike since the gap between sill group $\mathrm{X}$ and $\mathrm{Y}$ changes from $100 \mathrm{~m}$ to $1500 \mathrm{~m}$ from south to north. The geochemical signature of sills at Site 857 were generated from a more evolved melt than the sills at Site 855 (Shipboard Scientific Party, 1992c) rendering it unlikely that all interpreted reflections originated from a single flow.

The sediments at Site 857D are underlain by a sill-sediment complex. Reflections from the topmost sills are two to three times that of the seafloor reflection but below that, interference of reflections from the tops and bottoms of sills results in a low-frequency low-amplitude wave-train. Recent hydrothermal vents are associated with small (dimensions on the order of a kilometer laterally and tens of meters thick), shallow basalt flows or intrusions. These basalt flows are considerably smaller in their along-strike dimension than the sills that floor the sedimentary section.

The transition from lithologic Unit I to II as defined in Hole 857A has been correlated to a small reflection that is uplifted and merges 

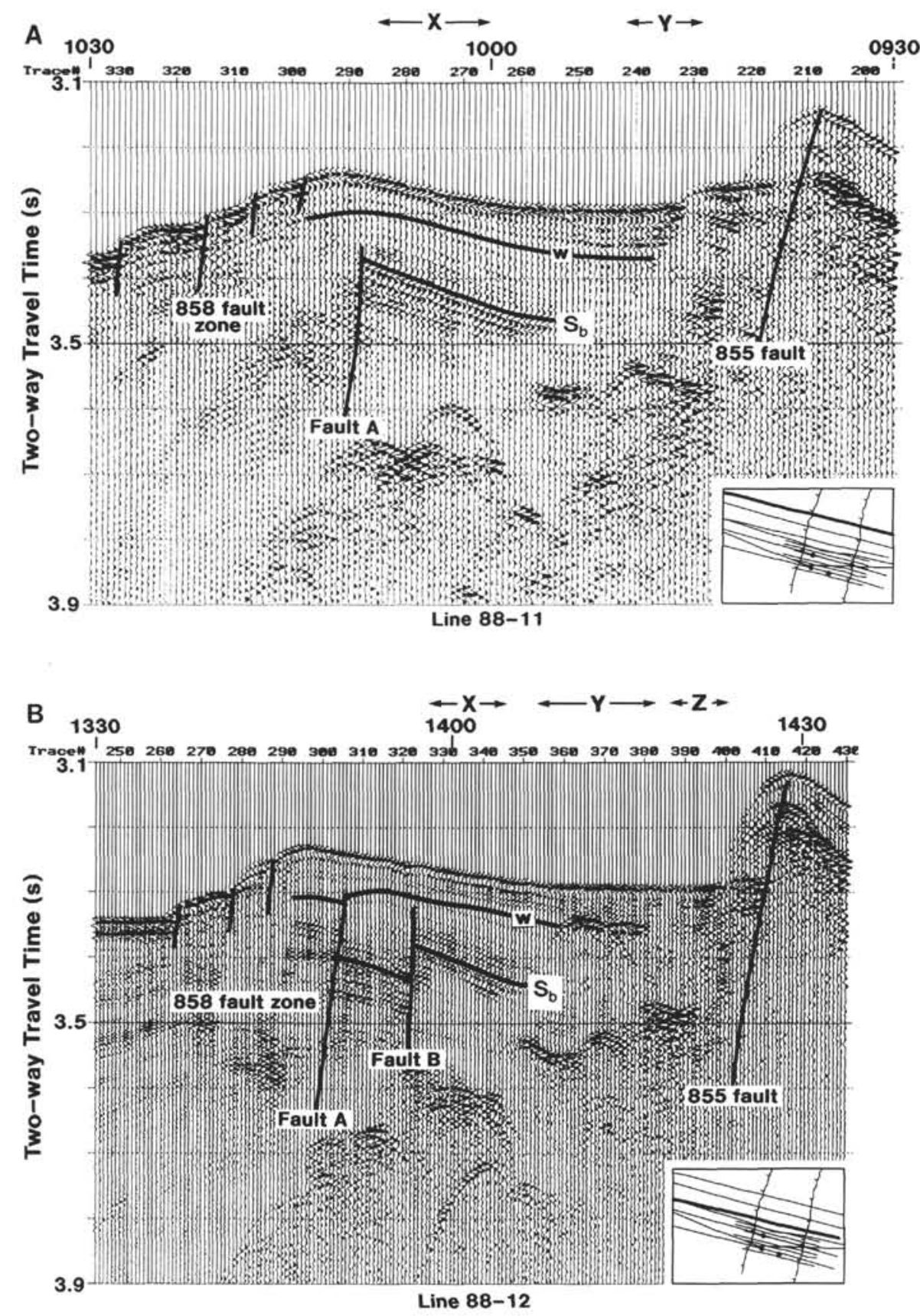

Figure 4. Interpreted sections of single-channel data collected in 1988. Interpreted sill groups W, X, Y, and Z are shown with arrows. The base of the wedge of reflectors, which indicates tilting during faulting, has been labeled "w" on each section. Reflector $\mathrm{S}_{\mathrm{b}}$ has been chosen because its amplitude allows us to trace it across faults and from section to section with some confidence. Insets show cartoon of Fig. 2; bold line indicates profile location.

into the seafloor reflection to the east. The lithologic subunit IIA to IIB boundary cannot be mapped across the small-offset normal faults, $\mathrm{C}$ and $\mathrm{A}$, implying either that this alteration front is local or that its signature varies considerably according to the stratigraphic sequence in which it occurs. Timing of alteration relative to faulting is problematic.

The top $225 \mathrm{~m}$ of sediments east of Site 856 have a velocity of $1730 \mathrm{~m} / \mathrm{s}$, similar to the interval velocity at Site 857 over the same depth (Rohr and Gröschel-Becker, this volume). Seafloor reflection coefficients immediately adjacent to the vent are within the range expected for unconsolidated deep-sea turbidites, 0.15-0.2 (Rohr et al., 1993). From these observations we conclude that the alteration which formed massive sulfides has produced little regional alteration.
Since Middle Valley is a failed rift, it could be dangerous to draw conclusions about normal seafloor spreading from its structure. It is evident, however, that tectonic and volcanic activity have been active throughout this 7-km-wide zone during the late Pleistocene and possibly into the Holocene. The 855 fault has effectively cut off crust to the east from recent volcanism while remaining an active fault.

\section{ACKNOWLEDGMENTS}

Thanks to E.E. Davis for making the single-channel seismic reflection data available, R. Franklin for drafting, and J. Austin, A. Fisher, G. Moore, and D. Mosher for improving the manuscript. This is Geological Survey of Canada manuscript \#25493. 

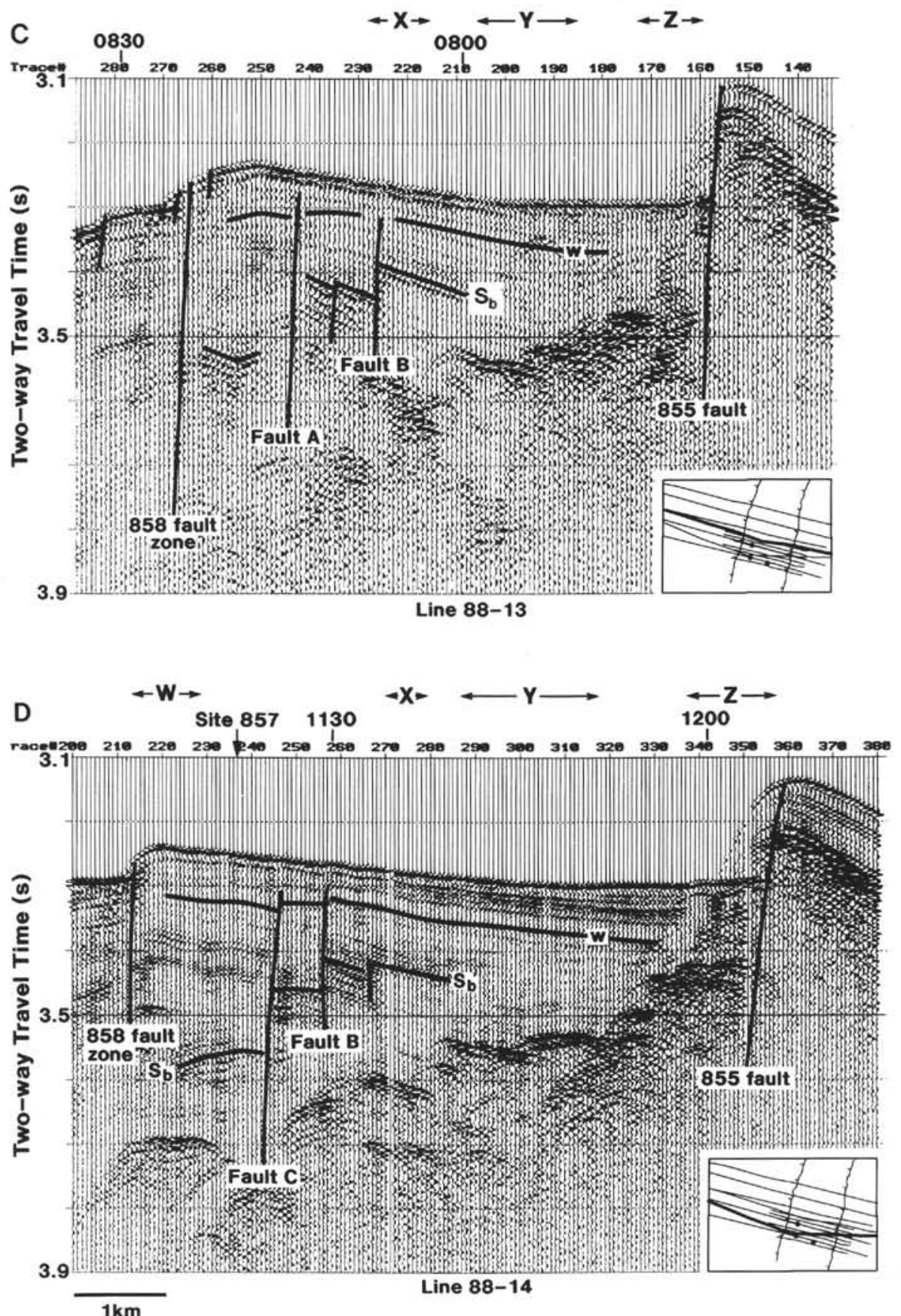

Figure 4 (continued). 


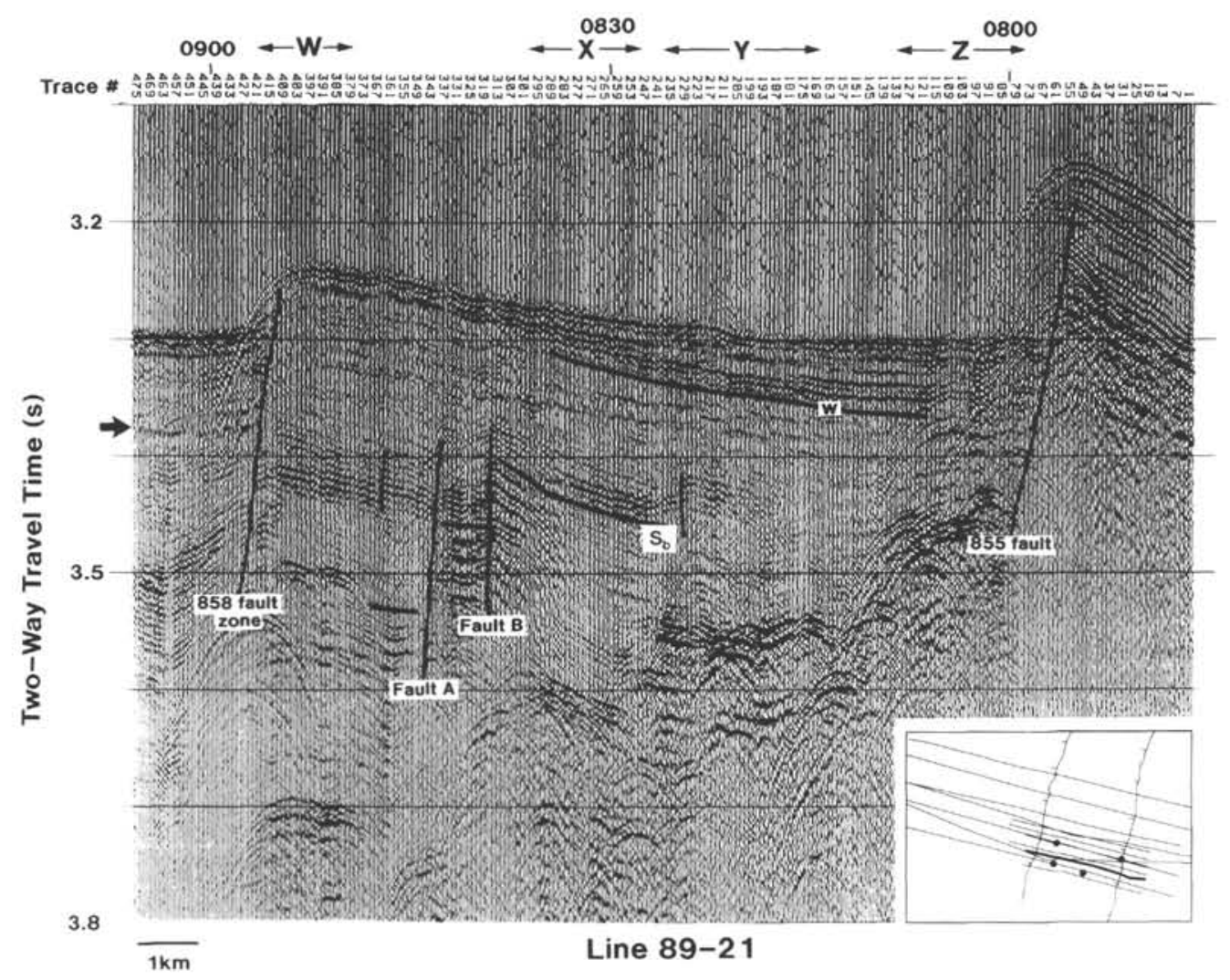

Figure 5. Single-channel profile across the eastern side of Middle Valley. At the seafloor the 858 fault zone is offset $40 \mathrm{~m}$; compare to line 88 -11 (Fig. $4 \mathrm{~A}$ ) $7 \mathrm{~km}$ north where the 858 fault zone has a larger offset and consists of several strands. A wedge of tilted reflectors is also obvious immediately below the seafloor west of the 855 fault. Inset shows cartoon of Fig. 2; bold line indicates profile location.
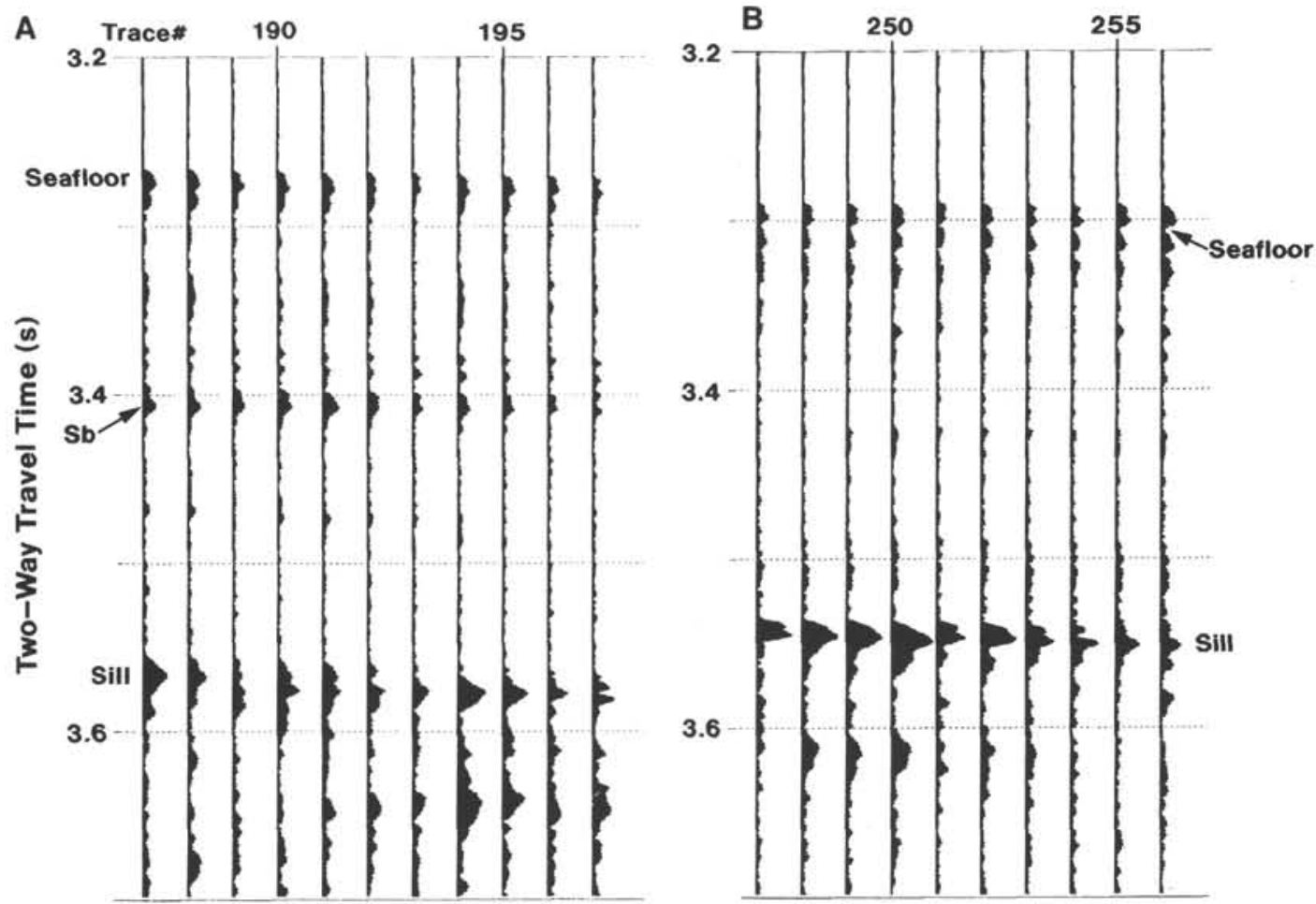

Figure 6. Hilbert transform of two groups of reflectors from line 89-20 (Fig. 3). This amplitude envelope of the traces demonstrates that bright events between 3.5 and $3.6 \mathrm{~s}$ have amplitudes $2-3$ times that of the seafloor. A. Sedimentary reflector $\mathrm{S}_{\mathrm{b}}$ has an amplitude equivalent to the seafloor and significantly brighter than other sedimentary reflectors. B. Traces further east show reflections from an interpreted sill and sedimentary reflectors much smaller than the seafloor. 


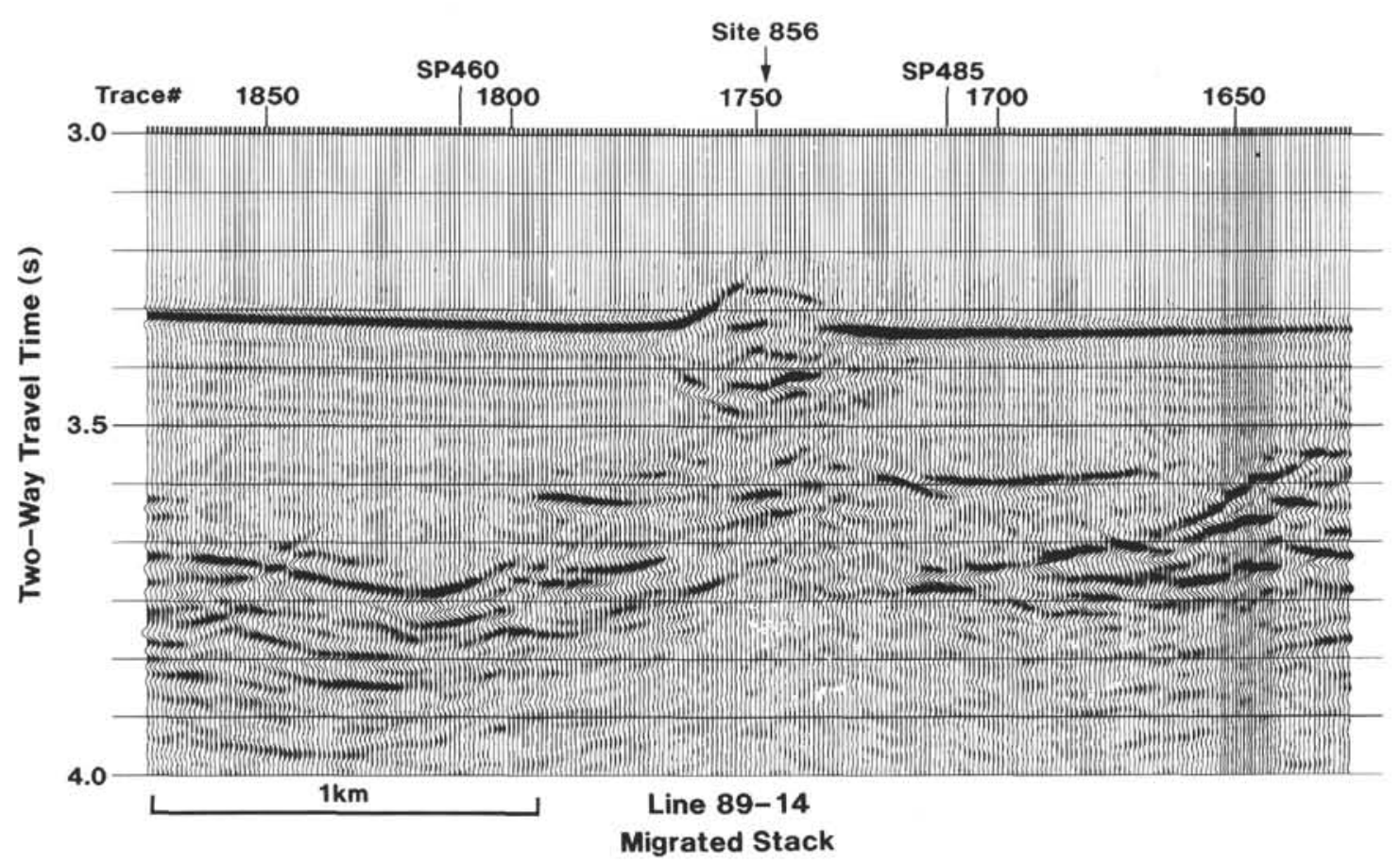

Figure 7. Migrated section of line 89-14 over Site 856, a hill with massive sulfide mounds. A bright reflector $150-180$ ms under the hill is interpreted to be the base of basalt. Other bright events (below $3.6 \mathrm{~s}$ ) in the section are the pervasive sills that intrude sediments and comprise upper crust in Middle Valley.

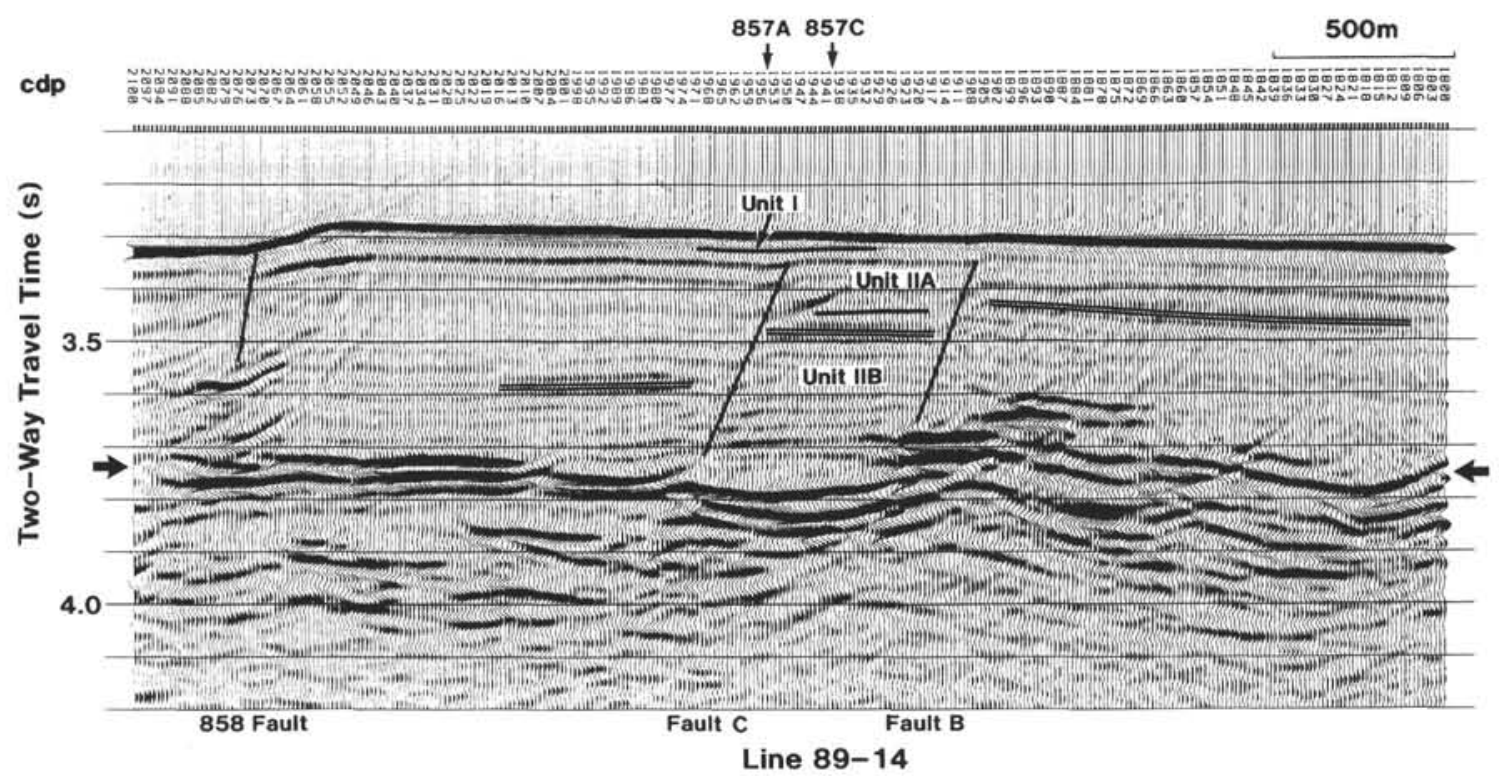

Figure 8. Detail of migrated stacked section over Site 857. Unit I/II boundary as defined at Hole 857A has been drawn as a thin black line; subunit IIA/IIB boundary is marked by the thin line at $3.45 \mathrm{~s}$ under Hole $857 \mathrm{C}$. Fault $\mathrm{C}$ lies between Holes $857 \mathrm{~A}$ and $857 \mathrm{C}$. Arrows mark the top of the sill-sediment complex that is considered to be the top of basement. Double lines mark a reflector that can be correlated across the faults. 


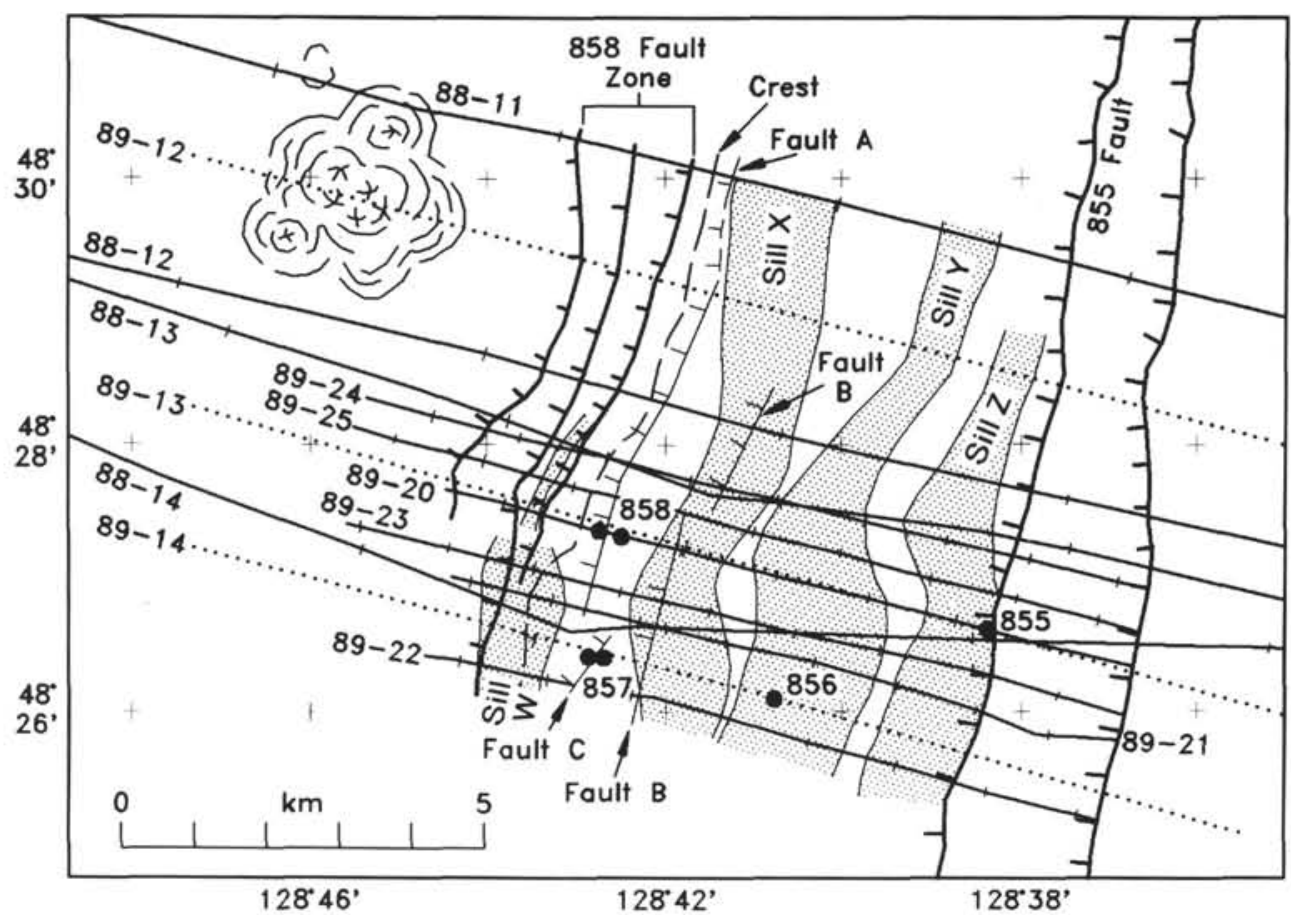

Figure 9. Map of sills and faults in fault block drilled during Leg 139 as interpreted from seismic reflection data.

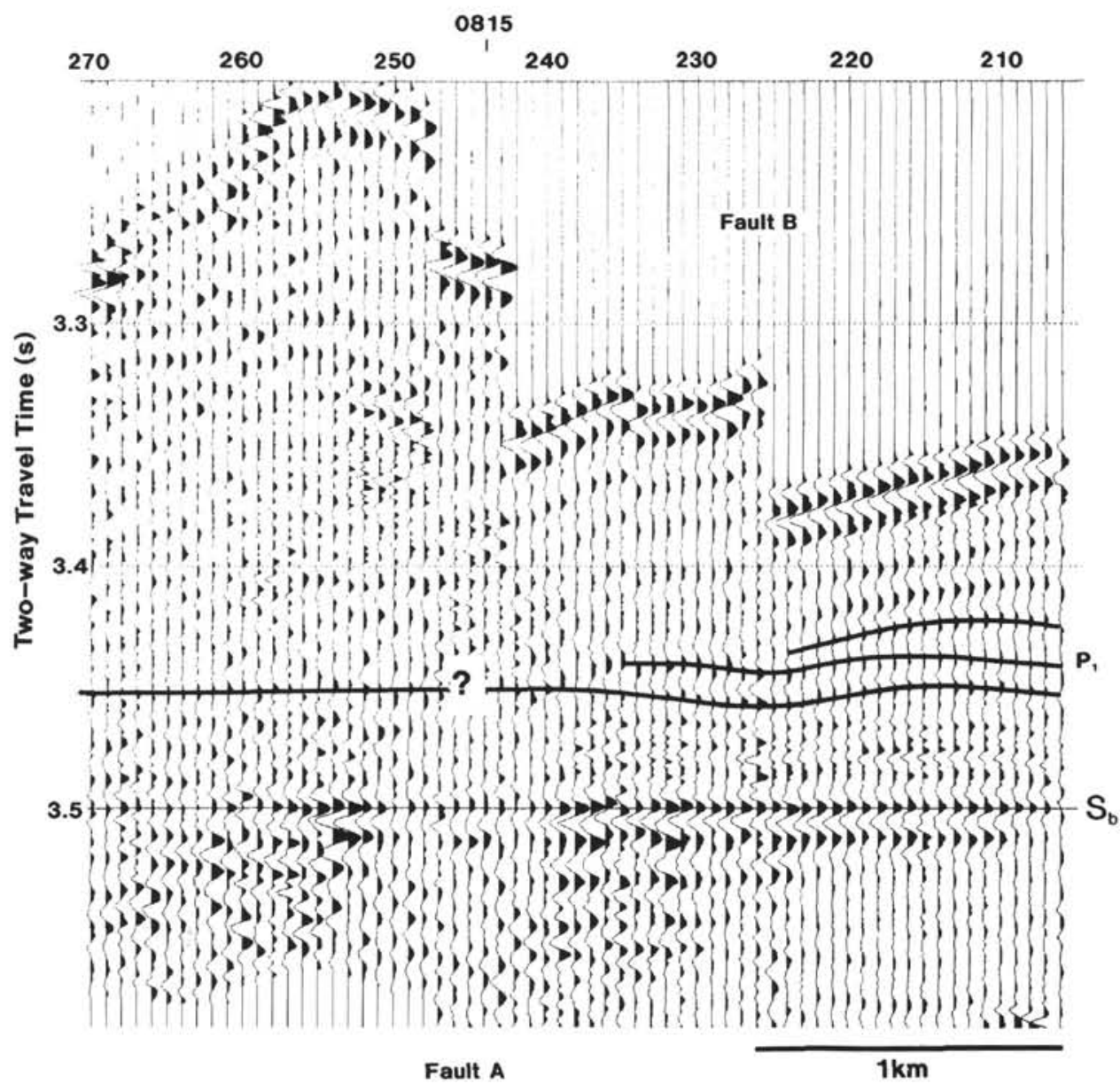

Figure 10. Line 88-13 (traces 206-270) has been flattened along horizon $\mathrm{S}_{\mathrm{b}}$, which restores the section before movement on faults A and B. Correlation of sedimentary events is good $70 \mathrm{~ms}$ above $\mathrm{S}_{\mathrm{b}}$ (between $\mathrm{S}_{\mathrm{b}}$ and lowest solid line) across fault $\mathrm{B}$ but questionable across fault $\mathrm{A}$. Events that are angularly unconformable to $P_{1}$ can only be mapped east of fault $C$ and must represent sediments deposited after movement began. 


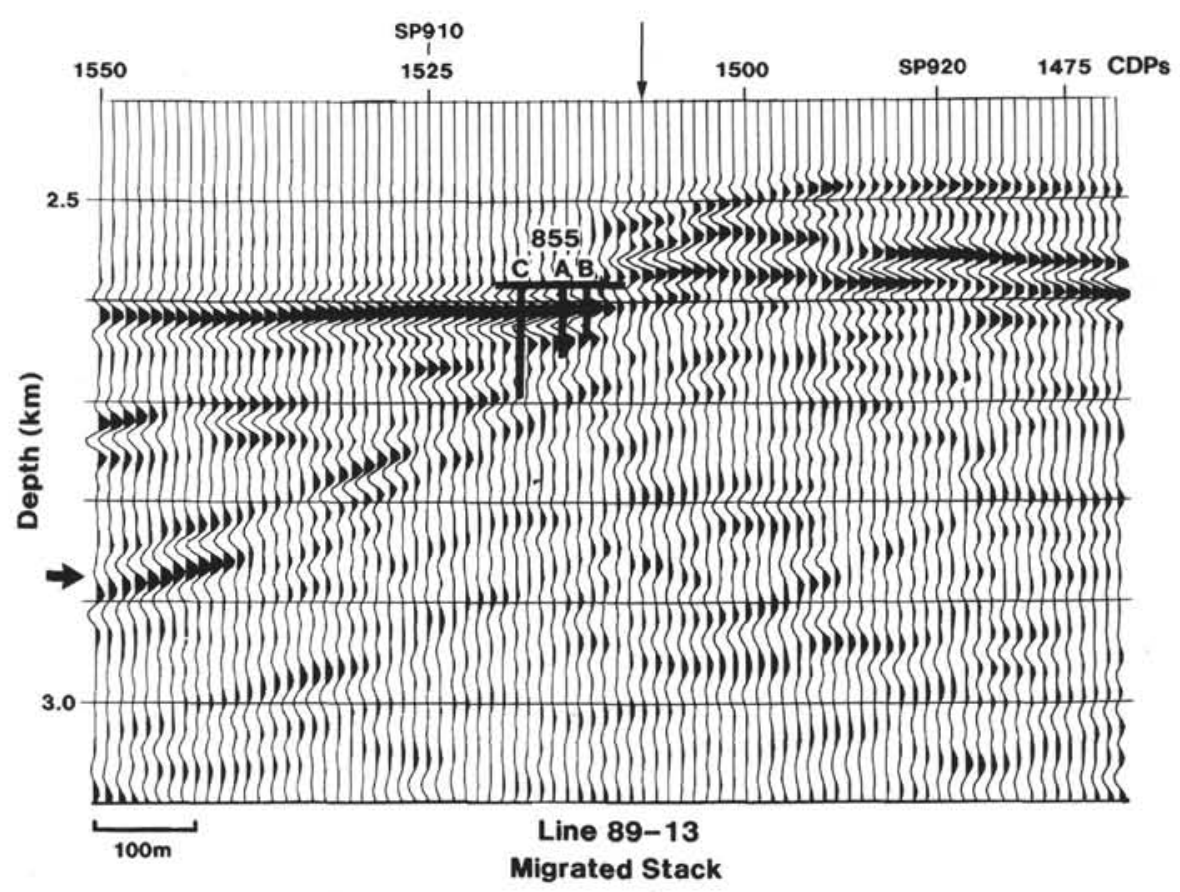

Figure 11. Line 89-13 migrated into depth and displayed in a 1:1 section for a velocity of $2 \mathrm{~km} / \mathrm{s}$. Holes $855 \mathrm{~A}$, B, and C are drawn to the depths they penetrated. Their relative positions are accurate, while the exact location of the fault trace on the seafloor is ambiguous because of the low frequencies. Arrow marks probable sediment-basement contact.

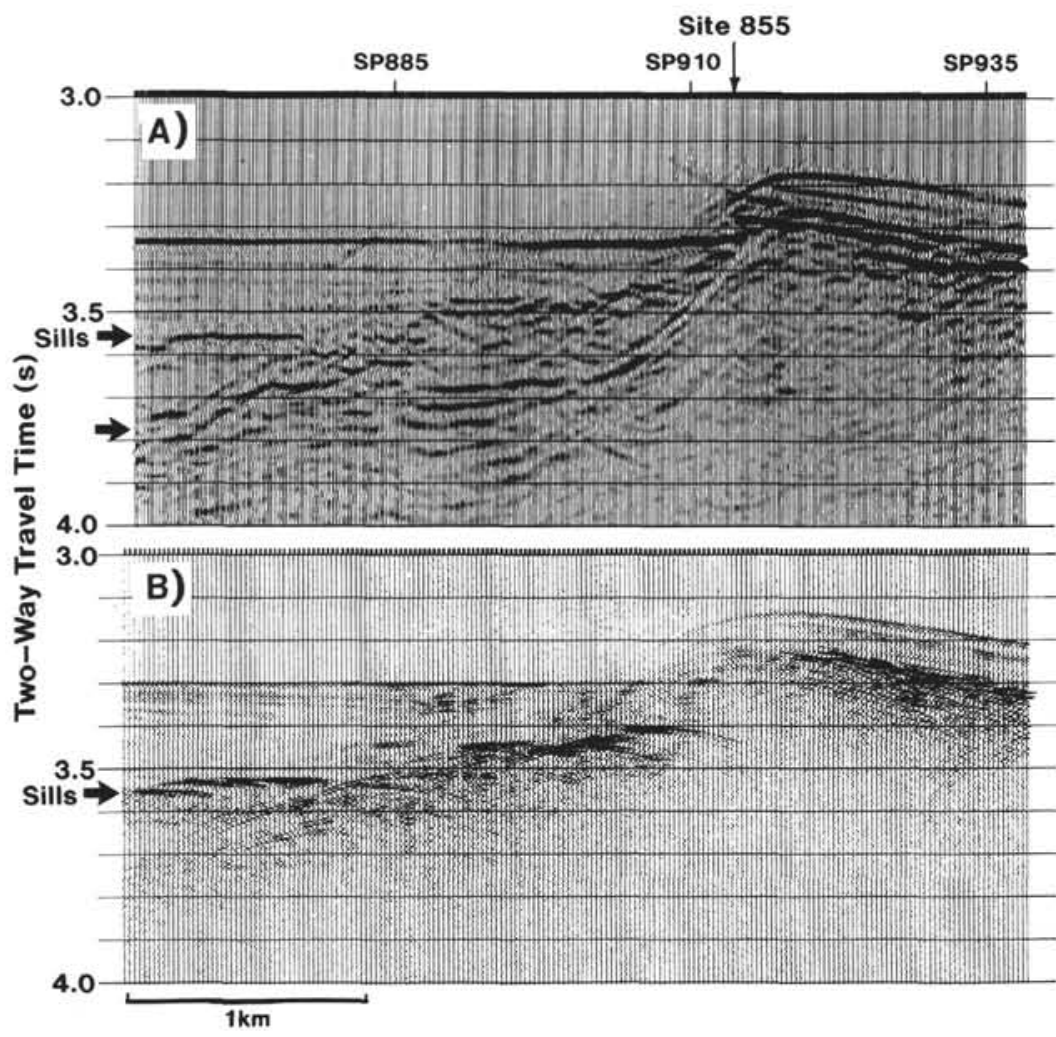

Figure 12. A. Multichannel line 89-13. B. Single-channel line 89-20. Both profiles are displayed at identical vertical and horizontal scales. The single-channel data has a higher frequency content as well as less penetration than the multichannel data. Sills between 3.6 and $3.7 \mathrm{~s}$ are not observed in the single-channel data, giving a false impression of where true basement begins. 
Figure 13. Single-channel line 88-14 seafloor reflections have been aligned and flattened at $3.3 \mathrm{~s}$. This plot demonstrates lack of correlation of sediment reflector sequence and thickness across the normal fault adjacent to Site 855 , as well as disturbance of reflection sequence west of the 855 fault.

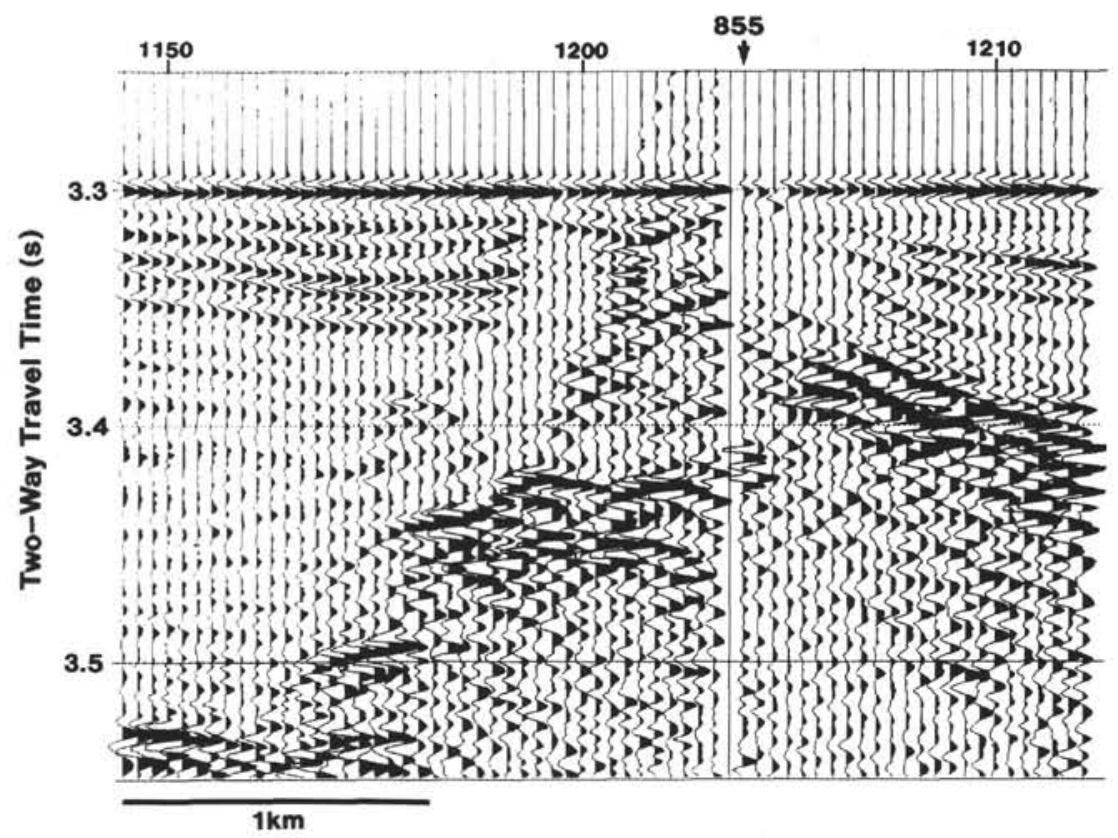

Site 856

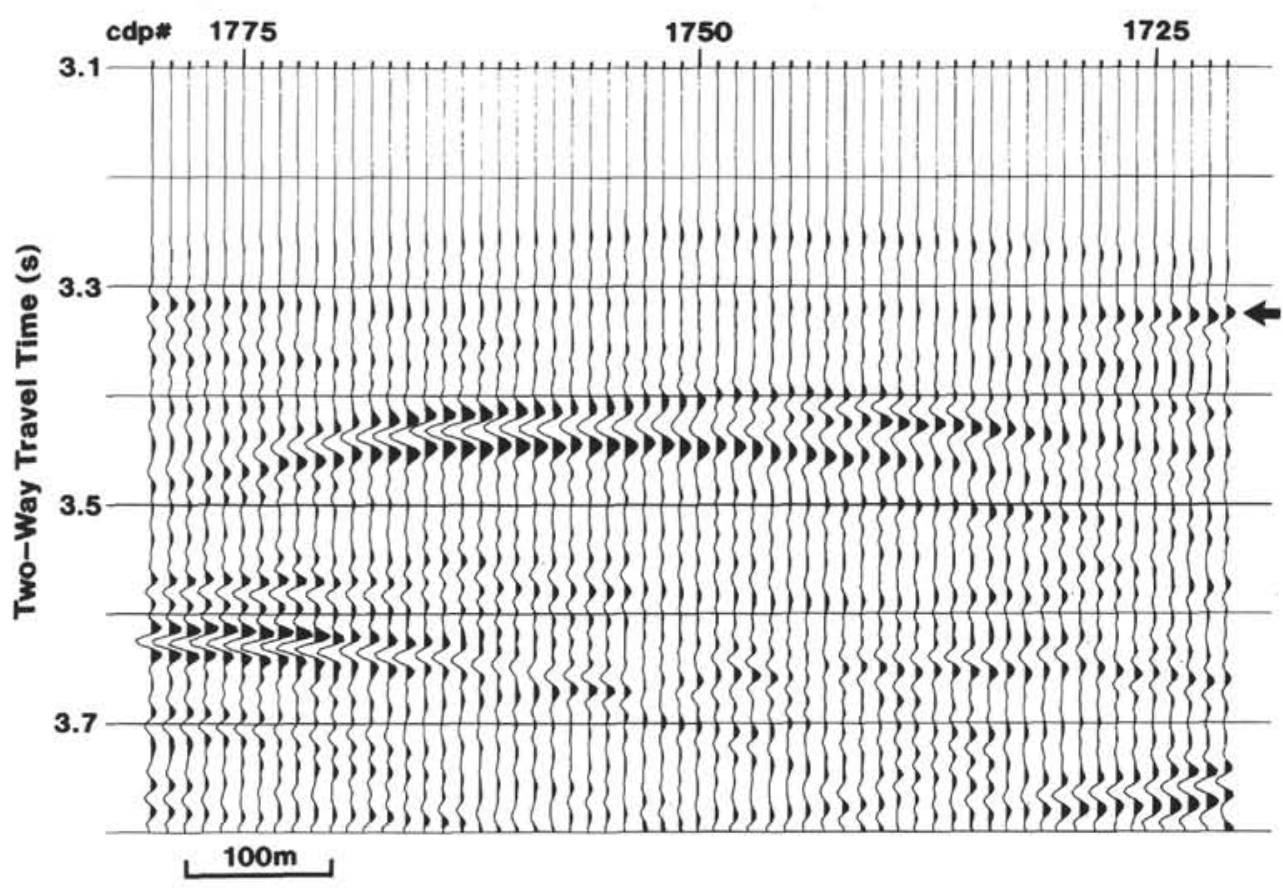

Figure 14. Seismic reflection data from the trace on the multichannel streamer closest to the airgun array. Reflections and diffractions from the hill comprise the first small amplitude event; seafloor is marked by the arrow. The bright event at $3.4 \mathrm{~s}$ is interpreted to be a sill underlain by sediments. 


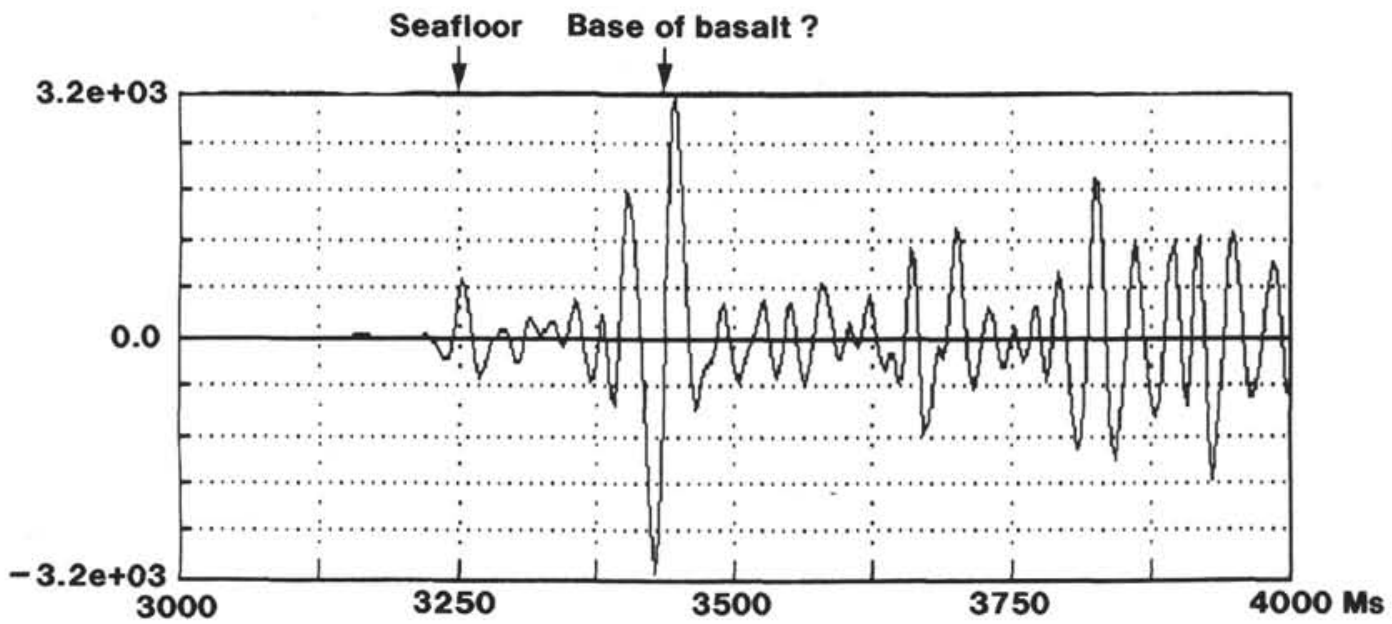

Figure 15. Near trace of cdp 1750 (line 89-14, shotpoint 475) over Site 856. The seafloor is a positive small-amplitude event. The large event at $3400 \mathrm{~ms}$ has reversed polarity and probably marks the base of sills under the hill.

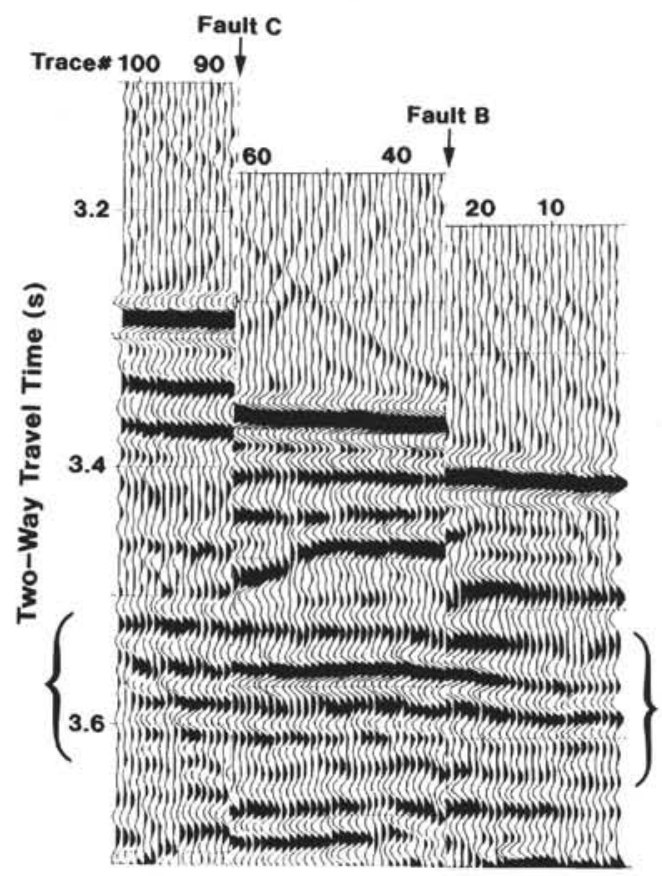

Figure 16. Data from line 89-14 (Fig. 8, cdp 1880-1980); a sequence of three events followed by two weak events can be correlated across faults $\mathrm{C}$ and $\mathrm{B}$. Section disrupted by fault plane has been omitted.

\section{REFERENCES}

Davis, E.E., and Villinger, H., 1992. Tectonic and thermal structure of the Middle Valley sedimented rift, northern Juan de Fuca Ridge. In Davis, E.E., Mottl, M.J., Fisher, A.T., et al., Proc. ODP, Init. Repts., 139: College Station, TX (Ocean Drilling Program), 9-41.

Rohr, K., Davis, E.E., and Hyndman, R.D., 1992. Multi-channel seismic reflection profiles across Middle Valley, northern Juan de Fuca Ridge. Open-File Rep.-Geol. Surv. Can., 2476.

Rohr, K.M.M., Schmidt, U., and Gröschel-Becker, H., 1993. Regional patterns of hydrothermal alteration of sediments as interpreted from seafloor reflection coefficients, Middle Valley, Juan de Fuca ridge. Geophys. Res. Lett., 20:1867-1870.

Abbreviations for names of organizations and publications in ODP reference lists follow the style given in Chemical Abstracts Service Source Index (published by American Chemical Society).
Shipboard Scientific Party, 1992a. Site 855. In Davis, E.E., Mottl, M.J., Fisher, A.T., et al., Proc. ODP, Init. Repts., 139: College Station, TX (Ocean Drilling Program), 101-160.

, 1992b. Site 856. In Davis, E.E., Mottl, M.J., Fisher, A.T., et al., Proc. ODP, Init. Repts., 139: College Station, TX (Ocean Drilling Program), 161-281.

, 1992c. Site 857. In Davis, E.E., Mottl, M.J., Fisher, A.T., et al., Proc. ODP, Init. Repts., 139: College Station, TX (Ocean Drilling Program), 283-429.

1992d. Site 858. In Davis, E.E., Mottl, M.J., Fisher, A.T., et al., Proc. ODP, Init. Repts., 139: College Station, TX (Ocean Drilling Program), 431-569.

Date of initial receipt: 1 March 1993

Date of acceptance: 10 September 1993

Ms 139SR-204 


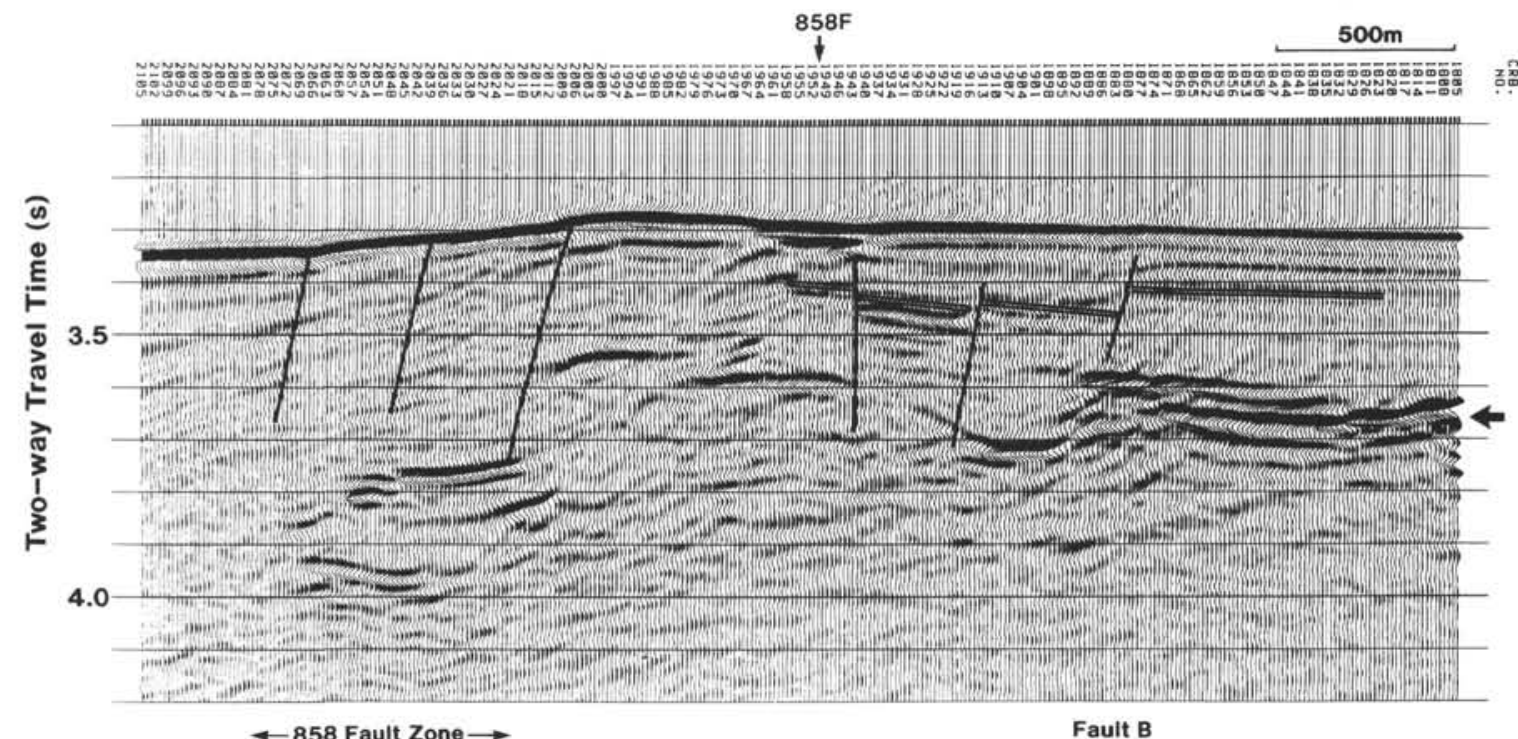

Figure 17. Detail of migrated stacked line 89-13 over Site 858. This section of line 89-13 and the section of $89-14$ shown in Fig. 8 are aligned on strike. The crest of the footwall has moved east, and the 858 fault zone has broadened. The top of the sill-sediment complex is similar in the east side of each line but significantly different west of fault B. Modelling of well log data (Rohr and Gröschel-Becker, this volume) shows that the bright reflector at $3.57 \mathrm{~s}$ below Hole $858 \mathrm{~F}$ is an extrusive basalt flow.

Figure 18. Comparison of single-channel sections immediately north of Site 858 . They have been correlated at horizon $\mathrm{S}_{\mathrm{b}}$ across fault $\mathrm{B}$. A. Line $89-24$ is $1 \mathrm{~km}$ north of the Site; $\mathrm{S}_{\mathrm{b}}$ and associated events are relatively undisrupted in comparison to line 89-25 (B), on which $\mathrm{S}_{\mathrm{b}}$ has greater dip than other lines. Line $89-25$ is $500 \mathrm{~m}$ north of Site 858.

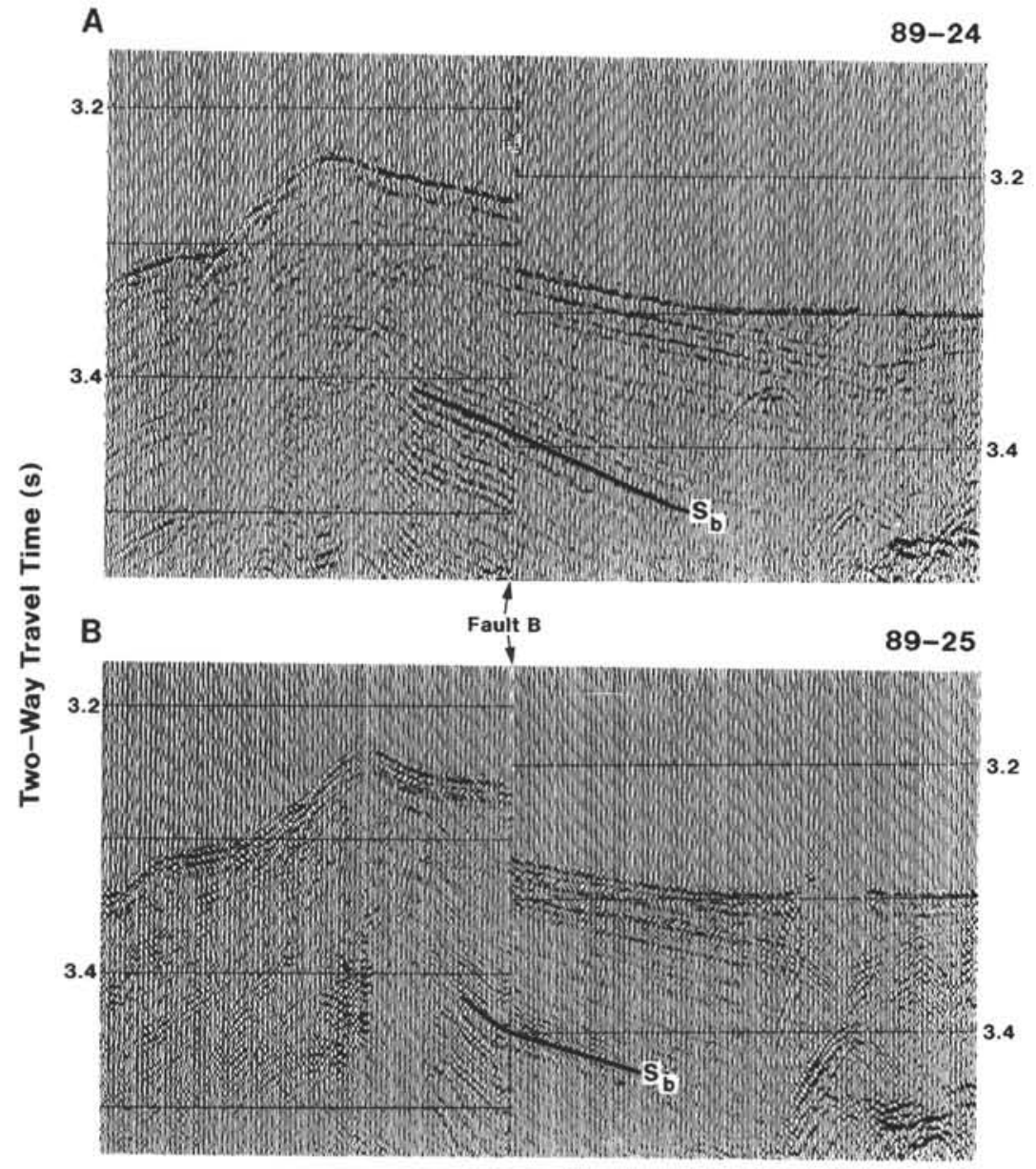




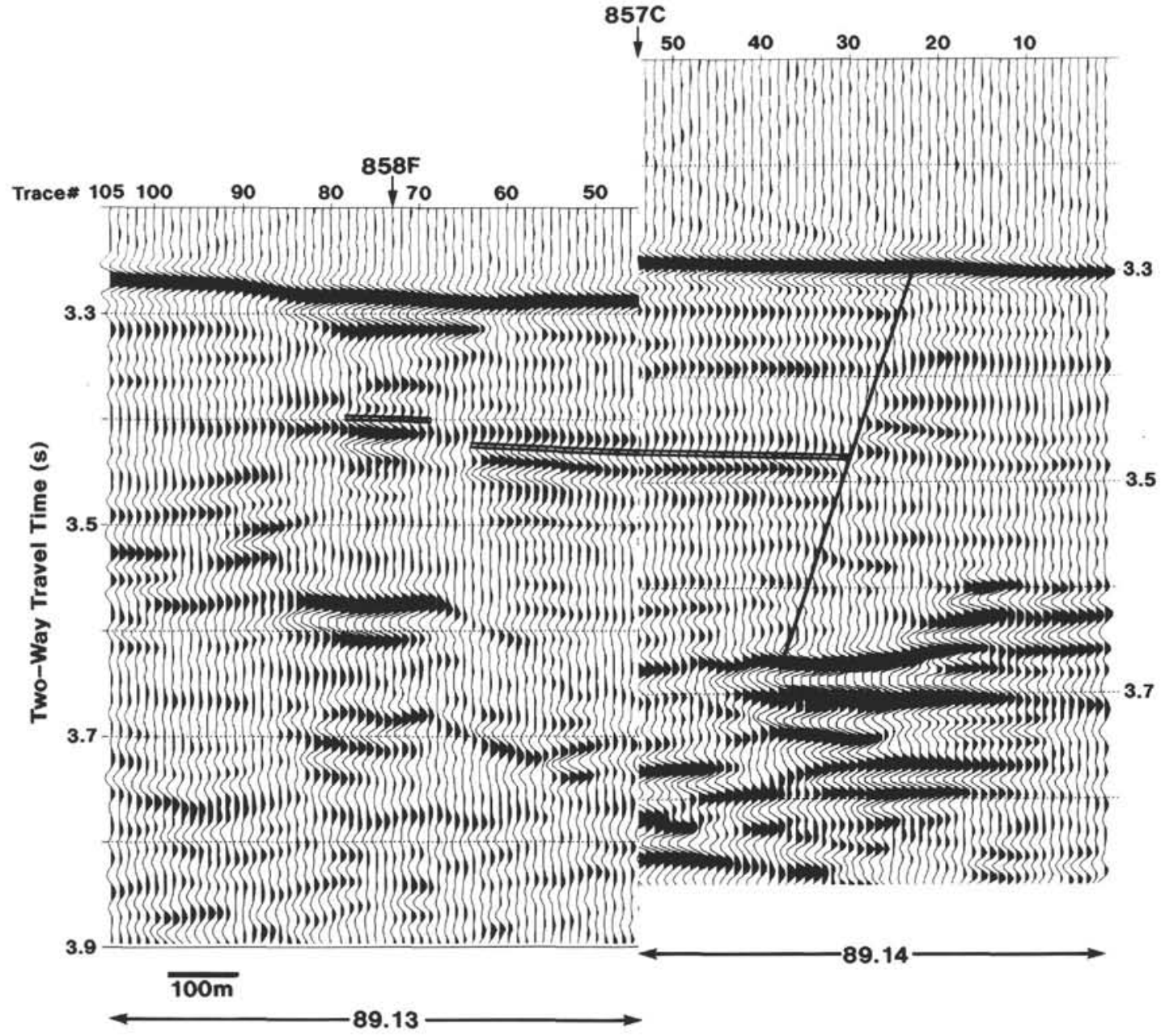

Figure 19. Correlation of stratigraphic horizons between multichannel lines showing uplift associated with off-axis volcanic rocks drilled under Hole $858 \mathrm{~F}$. Correlation is also based on log correlations. 